\title{
DECAPOD CRUSTACEANS OF THE TRAWLABLE SEA BED AROUND THE ISLAND OF LAMPEDUSA (CENTRAL MEDITERRANEAN)
}

\author{
BY \\ L. FALCIAI \\ Department of Environmental Biology, University of Siena, Via delle Cerchia, 3, I-53100 Siena, \\ Italy
}

\begin{abstract}
A list of species of the decapod crustaceans collected during benthic investigations around the island of Lampedusa is given, together with notes on their ecology and biology. The carcinofauna is typical for the central Mediterranean, and has a close affinity to that of the western basin. The Atlantic species Pilumnus inermis is reported for the first time in the central Mediterranean. Paguristes streaensis, hitherto known from the southern Adriatic, was also found.

\section{RIASSUNTO}

Viene riportato un elenco delle specie, con relative annotazioni ecologiche e biologiche, di Crostacei Decapodi raccolte durante una serie di campionamenti sui fondali circostanti l'Isola di Lampedusa. La carcinofauna è quella tipica del Mediterraneo centrale e presenta forte affinità con quella del bacino occidentale. Si segnala il ritrovamento, per la prima volta in Mediterraneo Centrale, della specie atlantica Pilumnus inermis e la presenza di Paguristes streaensis catturata finora nell' Adriatico meridionale.
\end{abstract}

\section{INTRODUCTION}

During investigations performed in September 1984 by a group of scientists of the Department of Animal Biology and Genetics of Florence University (Drs M. Borri, P. Mannini and C. Volpi) in the framework of a long term programme on the benthic fauna of the trawlable sea bed around the island of Lampedusa (central Mediterranean), many specimens of decapod crustaceans were collected. These specimens have been awaiting examination and classification at the Zoological Museum "La Specola" in Florence.

Although the ecology and biology of these taxa have been the subject of much research in the eastern (Holthuis \& Gottlieb, 1958; Koukouras, 1973; Pastore, 1976; Pastore \& Vaccarella, 1977; Manning \& Števčić, 1982; Lewinsohn \& Holthuis, 1986; Števčić, 1990; Galil \& Golani, 1990; Galil, 1992; Koukouras 


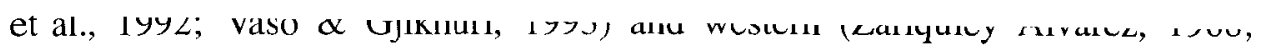
Carpine, 1970; Sardà \& Palomera, 1981; Manning \& Froglia, 1982; Castẹllon \& Abellò, 1983; Garcia-Raso, 1984; Pérès, 1985; Abellò \& Valladares, 1988; Abellò et al., 1988; Manning \& Holthuis, 1989; Cartes, 1993; d'Udekem d'Acoz, 1993; Mura \& Cau, 1994) basins of the Mediterranean, little is known about the carcinological communities of the central Mediterranean, especially the Sicilian Channel. Most studies concern trawling around the islands of Levanzo and Pantelleria (Sarà, 1969; Bombace \& Sarà, 1972) and research on the benthic fauna of the Maltese coasts (Števčić, 1979; Schembri \& Lanfranco, 1984). In the past, general studies have been performed on the fauna associations in Tunisian and Libyan waters (Colosi, 1923; Heldt, 1949, 1950; Forest \& Guinot, 1956 and more recently De Saint Laurent, 1971 and Arena \& Li Greci, 1973). Only Pipitone \& Tumbiolo (1993), however, have considered the benthic decapod and stomatopod fauna of the "Italian half" of the Sicilian Channel but did not examine the sea bed around the island of Lampedusa, possibly because of its position at the southwestern extremity of the Channel.

The aim of this study was to contribute to the knowledge of the carcinofauna in this geographical area and some aspects of the biology of the species found.

MATERIALS AND METHODS

The material was collected by trawling in an area southwest of the island of Lampedusa $\left(34^{\circ} 40^{\prime} 36^{\prime \prime}-35^{\circ} 25^{\prime} 86^{\prime \prime} \mathrm{N} 11^{\circ} 31^{\prime} 51^{\prime \prime}-12^{\circ} 31^{\prime} 51^{\prime \prime} \mathrm{E}\right)$ between depths of 40 and $70 \mathrm{~m}$ (fig. 1). A total of 90 hauls were made, 51 of which were at a depth of $40 \mathrm{~m}$, eight at $45 \mathrm{~m}, 27$ at $50 \mathrm{~m}$ and two each at 65 and $70 \mathrm{~m}$. For each haul, a common bottom trawl was towed at a speed of 3 knots (approx. $5.5 \mathrm{~km} / \mathrm{h}$ ) for about an hour.

The specimens, preserved in $70 \%$ alcohol, were classified according to the system proposed by Zariquiey Alvarez (1968), up-dated with the latest taxonomic revisions (Pastore, 1984; Falciai \& Minervini, 1992; Ingle, 1993). The total length (TL) of all specimens was measured using calipers or a micrometric microscope eye-piece. For Brachyura, carapace width (CW) was measured at the widest point (largest spines excluded). In natant forms, total length was measured from the tip of the rostrum to the tip of the telson. In Anomura and Brachyura, it was measured from the front to the posterior margin of the carapace. The presence of ovigerous females was noted. 


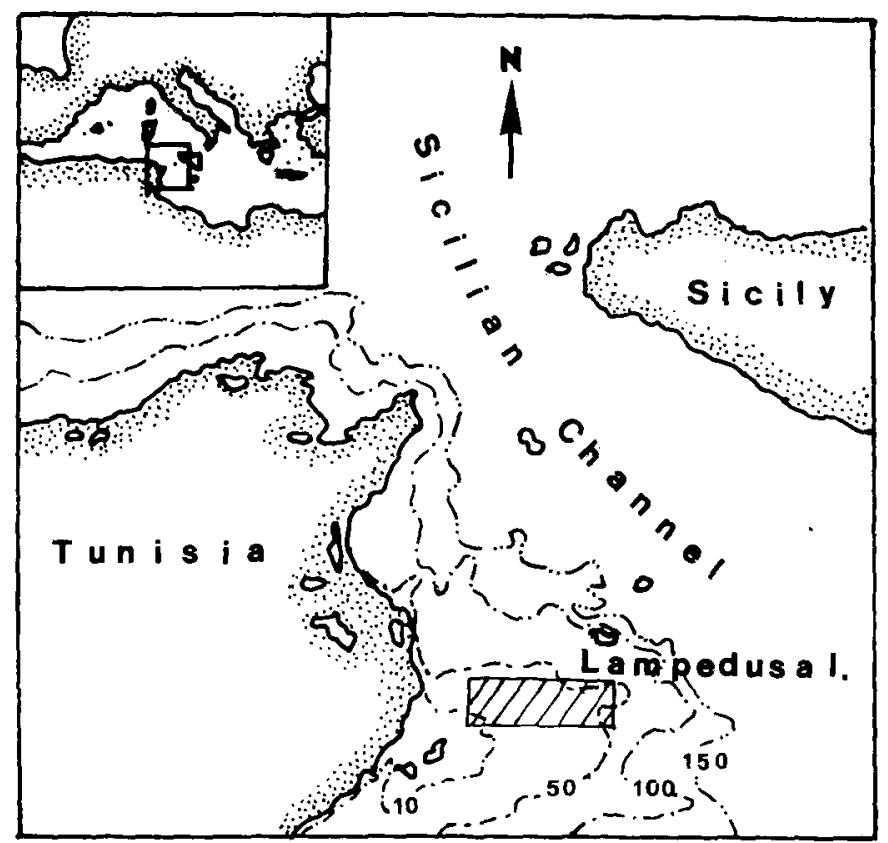

Fig. 1. Collecting zone off southwestern Lampedusa Isle.

\section{RESULTS}

The different number of hauls made at each depth prevented quantitative analysis of the data; however, it was possible to make a list of the species present in the area and interesting new biological and ecological information (reproductive periods, bathymetric distribution, etc.) was obtained for some of the species.

The taxonomical list appears in table I under the headings of abundance $(\mathrm{N})$, minimum and maximum dimensions $(\mathrm{mm})$ for males, females and ovigerous females, if found, the depth interval (D) at which specimens were found, and the type of substrate: $S=$ sand, $C S=$ coarse sand, $M=$ mud, $S / M=$ muddy sand, $\mathrm{M} / \mathrm{S}=$ sandy mud, $\mathrm{C}=$ coralligenous, $\mathrm{FA}=$ phanerogams (see Garcia Raso, 1984 and Vaso \& Gjiknuri, 1993). At the time of sampling, granulometric analysis of the sediment was not performed. The substrate data are based on simple visual observation and are only indicative of substrate type.

Specimens of decapods were found in 59 of the 90 hauls and totalled 281 individuals belonging to 37 species. Eight of these were Natantia, seven Anomura and 22 Brachyura. 


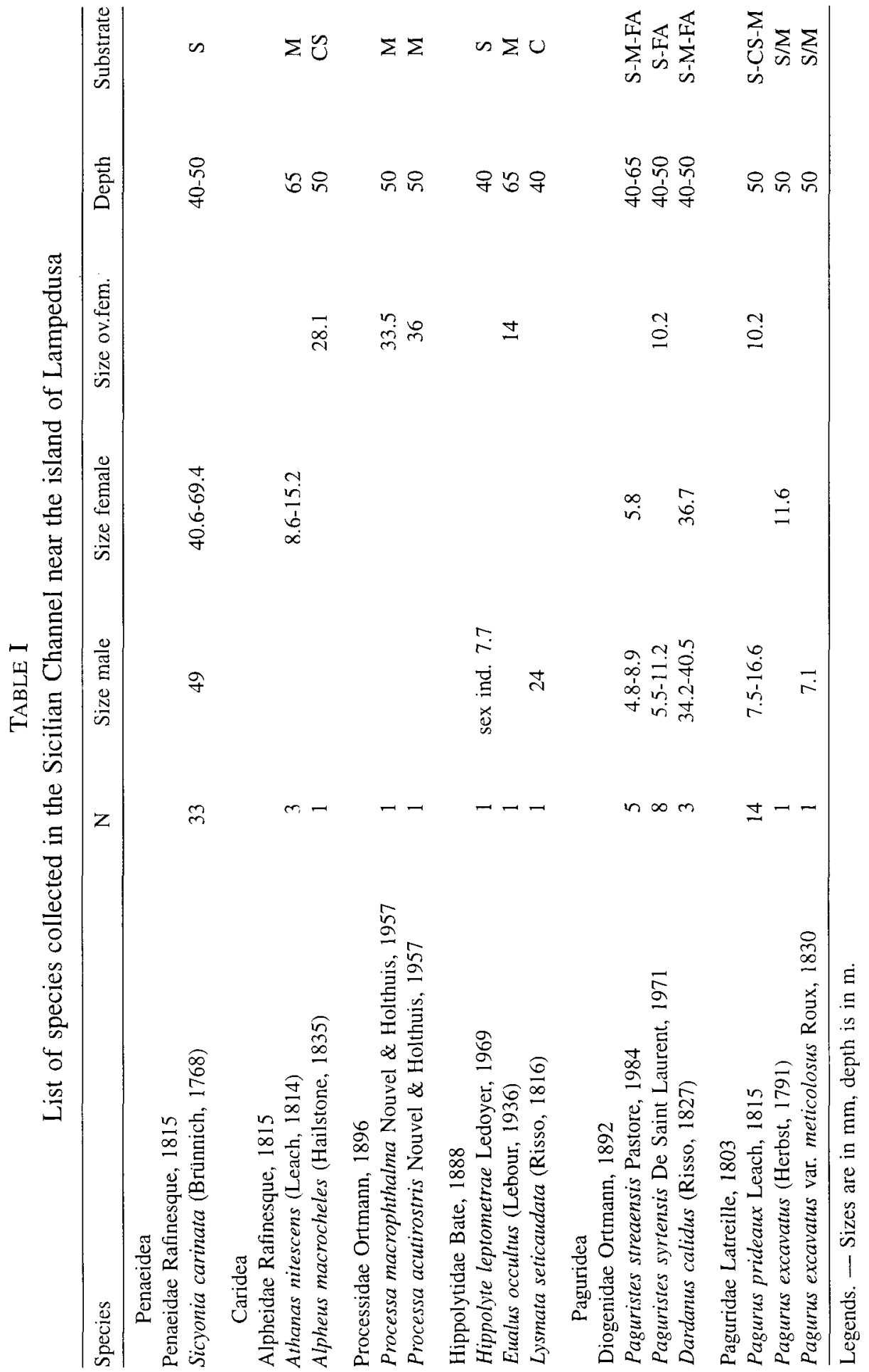




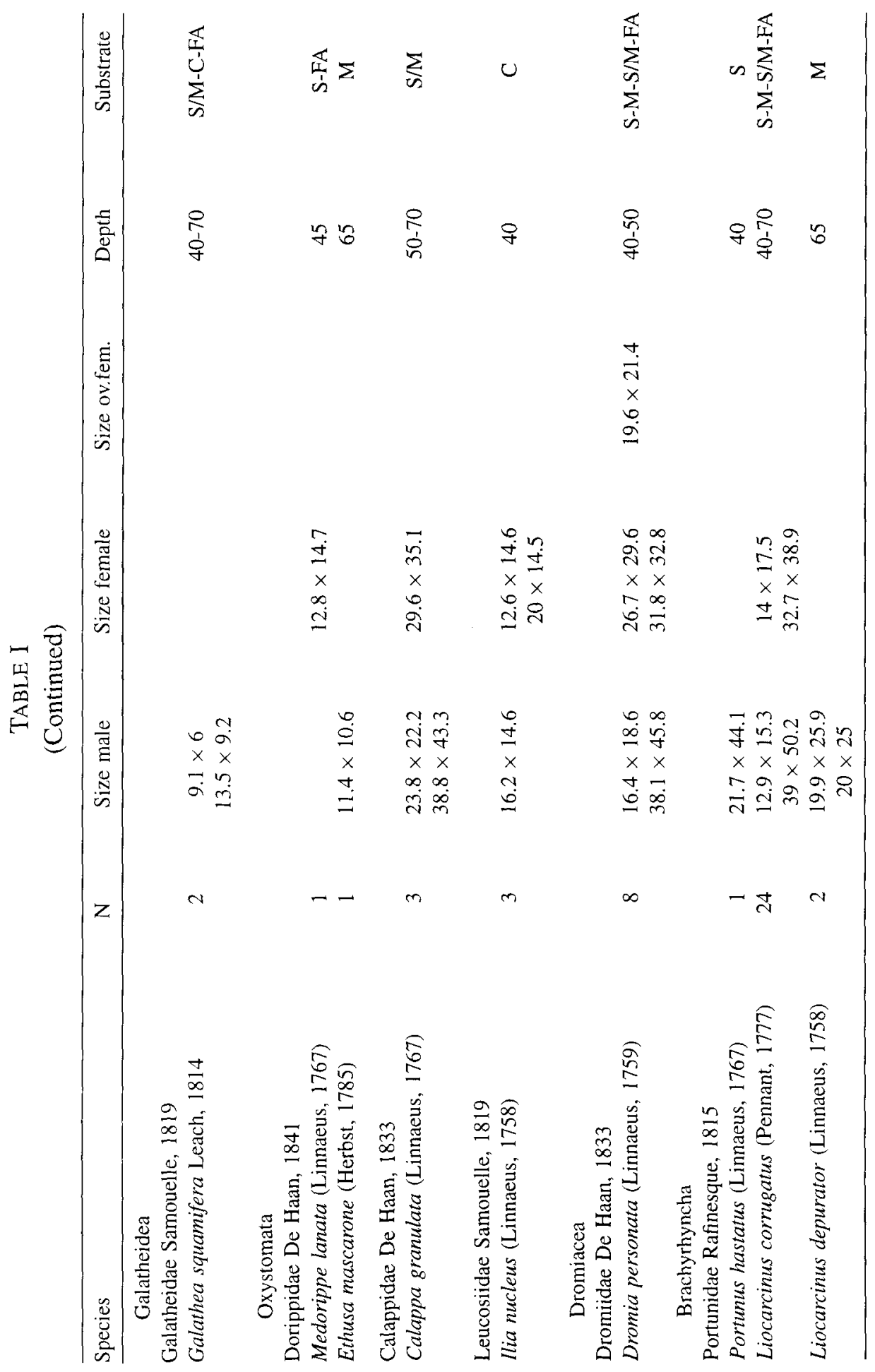




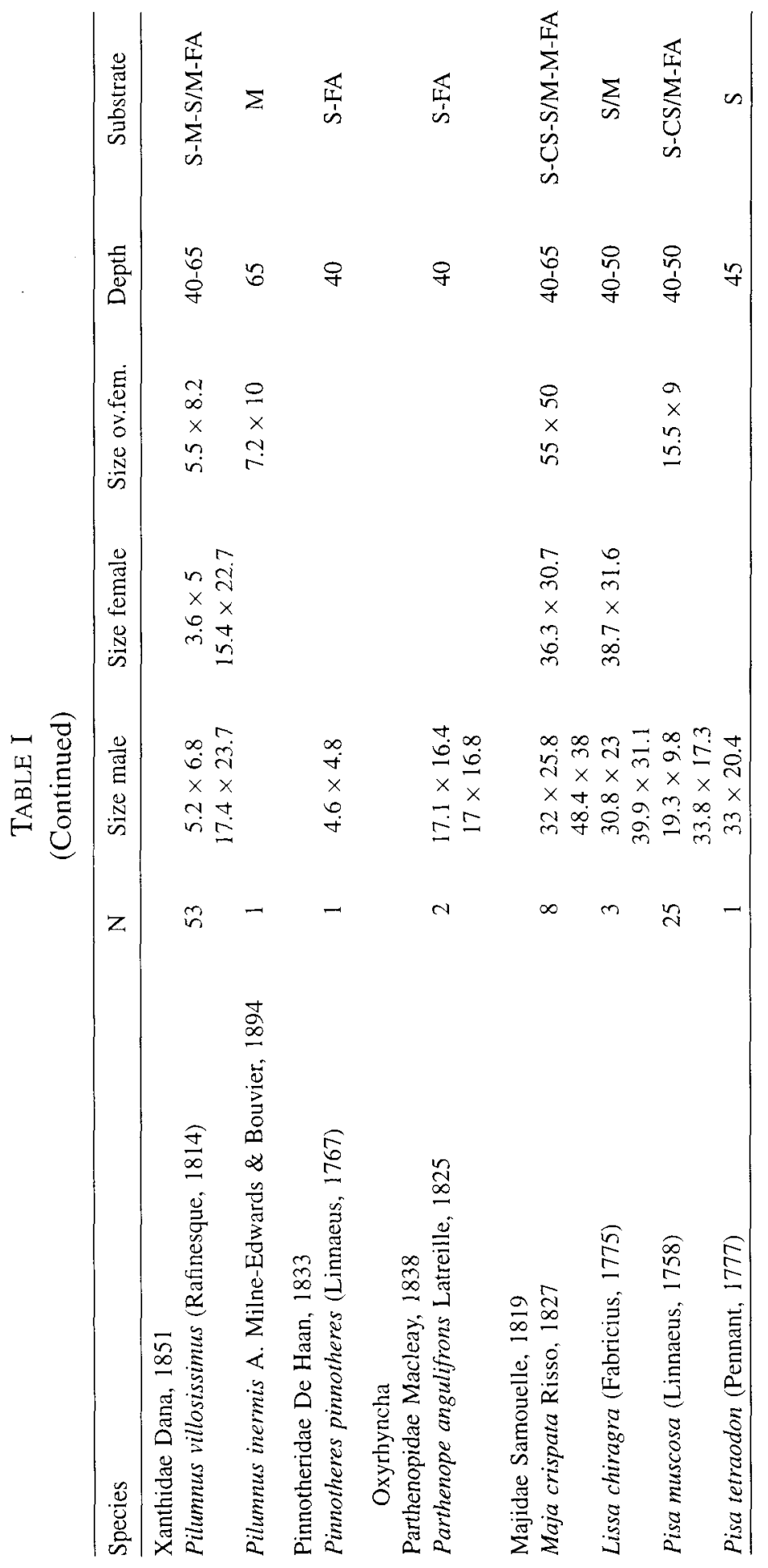




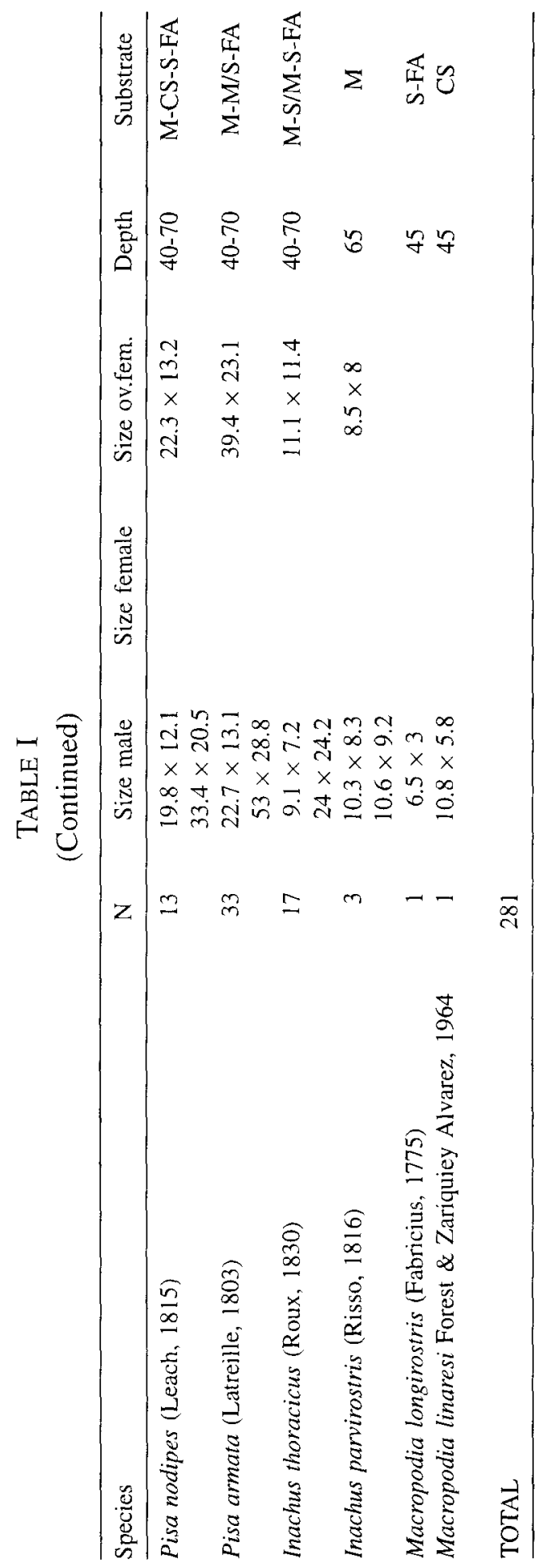


Processa macrophthalma Nouvel \& Holthuis, 1957 and Processa acutirostris Nouvel \& Holthuis, 1957 are two quite common species of shrimp in the Mediterranean. They generally live at a depth of 12-15 m (Nouvel \& Holthuis, 1957; Zariquiey Alvarez, 1968). In the study area, one ovigerous female of either species, corresponding in size to those reported in the literature, were found on muddy substrates at a depth of 50 metres.

Hippolyte leptometrae Ledoyer, 1969 belongs to a genus which is difficult to define because of wide intraspecific morphological variations, particularly of the juvenile forms. This genus has been the subject of continual revision and up-dating. In the study area, however, it was possible to identify (on the basis of branchiostegal spine distant from anterior margin of carapace) a young specimen $(\mathrm{TL}=7.7 \mathrm{~mm})$ of indeterminate sex, captured at a much shallower depth $(40 \mathrm{~m}$, sandy substrate) than in a previous report $(110 \mathrm{~m}$, muddy substrate cf. Detritici del Largo: Pérès \& Picard, 1964).

Eualus occultus (Lebour, 1936) is an Atlantic species which is very rare in the Mediterranean, where it lives at depths of 1-46 m (Zariquiey Alvarez, 1968). In the waters of Lampedusa, an ovigerous female ( $\mathrm{TL}=14 \mathrm{~mm}$ ) was found at $66 \mathrm{~m}$ on a compact mud substrate.

The material also included a male specimen $(\mathrm{TL}=24 \mathrm{~mm})$ of Lysmata seticaudata (Risso, 1816), captured at $40 \mathrm{~m}$ on a coralligenous substrate, even though it has been described (Zariquiey Alvarez, 1968) as common along all Mediterranean coasts at depths between $50 \mathrm{~cm}$ and $15 \mathrm{~m}$, in prairies of Posidonia oceanica (L.) Del.

Of the Anomura, specimens of Paguristes streaensis Pastore (1984) were found. This species has hitherto only been found along the Ionian (Bari harbour) and Greek coasts at 1-2 m on detritic substrates and prairies of Cymodocea nodosa (Ucria) Asch. In the study area, five specimens (4 males, 1 female) were caught at much greater depths (40-65 m) on different substrates: sand, mud, mud and detritus, and in prairies of Posidonia oceanica.

Paguristes syrtensis De Saint Laurent, 1971 has hitherto been found associated with prairies of Posidonia oceanica and at depths of 5-20 m and $250 \mathrm{~m}$ (De Saint Laurent, 1971) along the Tunisian coasts. The females are ovigerous from a length of $5 \mathrm{~mm}$ in the month of November. Of the eight specimens found in Lampedusa waters, two were ovigerous females $(\mathrm{TL}=10.2$ and $10.8 \mathrm{~mm})$. This species was found between 40 and $50 \mathrm{~m}$ on substrates of sand and in prairies of P. oceanica.

Pagurus excavatus (Herbst, 1791) is common throughout the Mediterranean and has hitherto been reported at 100-200 $\mathrm{m}$ (Zariquiey Alvarez, 1968) and 
beyond (550 m: Mura \& Cau, 1994). In the study area a male specimen ( $\mathrm{TL}=$ $7.1 \mathrm{~mm}$ ) was found at $50 \mathrm{~m}$ on a substrate consisting of mud and coarse sand.

The most numerous species (53 specimens) in the study area was Pilumnus villosissimus (Rafinesque, 1814). It is generally considered to live at shallow depths (1-2 m: Zariquiey Alvarez, 1968) and the females to be ovigerous from July to October when they have a total length of $16.5 \mathrm{~mm}$. In the study area, the species was found at practically all depths on different substrates: mud, mud mixed with sand and coralligenous bottoms, preferring sandy substrates in prairies of $P$. oceanica. Of the 14 ovigerous females found, one was sexually mature at a much smaller size than hitherto reported $(\mathrm{TL} \times \mathrm{CW}=5.5 \times 8.2 \mathrm{~mm})$.

An interesting finding among the material examined was a specimen of Pilumnus inermis A. Milne-Edwards \& Bouvier, 1894, because as far as is known, this is the first report from the central Mediterranean. Apart from the report of several specimens from the island of Alboran, in the extreme western Mediterranean, at a depth of 74-130 m (Garcia Raso, 1984), the only reports have been from the western coasts of Africa. $P$. inermis is generally considered to be a sublittoral species (15-30 m: Monod, 1956; Forest \& Guinot, 1966), though Nuñes-Ruivo (1961), Türkay (1976) and Forest \& Guinot (1966) found specimens at greater depths (110-440 m) off Morocco, Portugal and Madeira. It seems to prefer a coarse substrate of organogenous sand (Longhurst, 1958) or sponges, coral and rocky substrates encrusted with Gorgoniacea (Crosnier, 1964). Females are ovigerous from a length of $10 \mathrm{~mm}$ between February and April. It is therefore interesting that the present specimen was captured at a depth of $65 \mathrm{~m}$ on a compact mud substrate. It is also interesting that the specimen was an ovigerous female in a period and of a size (TL $\times \mathrm{CW}=7.2 \times 10 \mathrm{~mm}$ ) that do not correspond with previous reports for other areas.

Seventeen specimens of Inachus thoracicus (Roux, 1830), a very common species in the Mediterranean between 70 and $100 \mathrm{~m}$ (Zariquiey Alvarez, 1968), were found between 40 and $65 \mathrm{~m}$ on sandy, and sometimes slightly muddy, substrates. Three were ovigerous females.

Inachus parvirostris (Risso, 1816), reported from the Mediterranean (northern Adriatic and southern Tyrrhenian) at depths beyond $90 \mathrm{~m}$ on coralligenous and muddy substrates (Manning \& Froglia, 1982) was found at $65 \mathrm{~m}$ on a pure mud substrate. Three specimens, one of which was an ovigerous female $(\mathrm{TL} \times \mathrm{CW}$ $=8.5 \times 8 \mathrm{~mm}$ ), were found.

Finally, another species uncommon in the Mediterranean, which lives between 30 and $80 \mathrm{~m}$ on coarse sand substrates, was found: a male of Macropodia linaresi Forest \& Zariquiey Alvarez, 1964, was taken at a depth (46 m) and on a substrate (coarse sand), in line with previous reports (Zariquiey Alvarez, 1968). 
Examination of the specimens of decapod crustaceans collected on the sea bed at depths of 40-70 m southwest of the island of Lampedusa provided new information on the carcinofauna of the area and on the biology of some of the species found. Although the type of sampling did not permit quantitative analysis of the data, it can be said that the carcinological fauna of the trawlable sea bed consists mainly of Brachyura, of which the families Majidae (105 specimens of 10 species) and Xanthidae (53 specimens of Pilumnus villosissimus) were the principal components. Among the Natantia, the family Penaeidae was well represented with 33 specimens of Sicyonia carinata.

Of the 37 species collected (punctiform capture in 16 cases), only Pilumnus inermis is of Atlantic origin and its capture in the waters of Lampedusa is the first report from the central basin of the Mediterranean. Eualus occultus and Macropodia linaresi are quite rare in the Mediterranean. All the other species are well known and have a greater affinity with the fauna of the western basin than that of the eastern Mediterranean. Only the presence of Paguristes streaensis suggests an affinity with a type of carcinofauna typical of the eastern basin. This species, hitherto reported from the mediolittoral waters of the coasts of the southern Adriatic, now has its distribution extended to include Lampedusa.

None of the Lessepsian species from the Red Sea, often lately captured along the eastern coasts of the Mediterranean, seem yet to have reached and colonized the central Mediterranean.

The present observations enable the bathymetric distribution of many species to be extended, in some cases considerably, to greater (Processa macrophthalma, Processa acutirostris, Eualus occultus, Lysmata seticaudata, Pilumnus villosissimus, Pilumnus inermis, Paguristes streaensis) and smaller (Hippolyte leptometrae, Pagurus excavatus, Inachus thoracicus, Inachus parvirostris) depths.

Finally, for some species (Inachus parvirostris and Dromia personata), the period in which ovigerous females can be found is extended by about a month (until September) or, as in the case of Paguristes syrtensis, put forward by two months. Furthermore, the present finding of ovigerous females of Pilumnus inermis indicates that it has two distinct reproductive periods: that already known from February to April, and now also September.

\section{ACKNOWLEDGEMENTS}

The author expresses her sincere thanks to Drs M. Borri, P. Mannini and C. Volpi of the Department of Animal Biology and Genetics of the University 
of Florence for kindly providing the study material and for their collaboration and valuable suggestions during the preparation of this paper.

\section{REFERENCES}

Abellò, P. \& F. J. Valladares, 1988. Bathyal decapod crustaceans of the Catalan Sea (Northwestern Mediterranean). Mésogée, 48: 97-102.

Abellò, P., F. J. Valladares \& A. Castellón, 1988. Analysis of the structure of decapod crustacean assemblages off the Catalan coast (North-West Mediterranean). Mar. Biol., 98: 39-49.

ALMAÇA, C., 1985. Evolutionary and zoogeographical remarks on the Mediterranean fauna of Brachyuran crabs. In: M. MORAITOU-APOSTOLOPOUlou \& V. KioRTSIs (eds.), Mediterranean marine ecosystem: 347-366. (Plenum, New York).

- - 1989. Biogeographic notes on the mediterranean Brachyura. Crustaceana, 56 (1): 14-17.

ARENA, P. \& F. LI GRECI, 1973. Indagine sulle condizioni faunistiche e sui rendimenti di pesca dei fondali batiali della Sicilia occidentale e della bordura settentrionale dei banchi di sogliola Siculo-Tunisina. Quad. Lab. Tecn. Pesca, 1 (5): 157-201.

BOMBACE, G. \& R. SARÀ, 1972. La pesca a strascico sui fondali da -500 a -700 metri nel settore a sud-est di Pantelleria. Mem. Min. Mar. Mercantile, 33.

CARPINE, C, 1970. Écologie de l'étage bathyal dans la Méditerranée occidentale. Mém. Inst. océanogr. Monaco, 2: 1-146.

CARTES, J. E., 1993. Deep-sea Decapod fauna of the western Mediterranean: bathymetric distribution and biogeographic aspects. Crustaceana, 65 (1): 29-40.

Castellón, A. \& P. ABellò, 1983. Bathymetric distribution of some Reptantia Decapoda in the Catalan area (Spain). Rapp. Comm. int. Mer Méditerranée, 28 (3): 291-294.

Colosi, G., 1923. Crostacei Decapodi della Cirenaica. Mem. R. Com. Talassogr. Italiano, 104: $1-11$.

Crosnier, A., 1964. Fond de pêche le long des côtes de la République Fédérale du Cameroun. Cahiers O.R.S.T.O.M., (Océanogr.) nº spécial: 1-133.

D'Udekem D'ACoz, C., 1993. Contribution à la connaissance des Crustacés Décapodes Helléniques I: Brachyura. Bios (Macedonia, Greece), 1 (2): 9-47.

Falcial, L. \& R. Minervini, 1992. Guida dei Crostacei Decapodi d'Europa: 1-282 (Muzzio ed., Padua).

Forest, J. \& D. Guinot, 1956. Sur une collection de Crustacés Décapodes et Stomatopodes des mers tunisiennes. Bull. Stat. Océanogr. Salammbò, 53: 24-43.

GaliL, B. S., 1992. Eritrean Decapods in the Levant. Biogeography in motion. Bull. Inst. océanogr., Monaco, $\mathrm{n}^{\circ}$ spécial 9: 115-123.

Galil, B. S. \& D. Golani, 1990. Two new migrant Decapods from the Eastern Mediterranean. Crustaceana, 58 (3): 229-236.

GarCia Raso, J. E., 1984. Brachyura of the coast of southern Spain (Crustacea, Decapoda). Spixiana, 7 (2): 105-113.

HeldT, J. H., 1949. Sur la rencontre en Méditerranée du "Crabe à sardines" Polybius henslowi Leach, espèce essentiellement Atlantique. Notes Sta. oceanogr. Salammbô, 31: 1-8.

- - 1950. Note sur une petite collection de Crustacés Décapodes Reptantia de la région de Tunis. Bull. Soc. Sci. nat. Tunisie, 3 (2, 3, 4): 43-46.

HolThuis, L. B., 1961. Report on a collection of Crustacea Decapoda and Stomatopoda from Turkey and the Balkans. Zool. Verhand., Leiden, 47: 1-67. 
Holthuis, L. B. \& E. Gottlieb, 1958. An annotated list of the Decapod Crustacea of the Mediterranean coast of Israel, with an appendix listing the Decapoda of the eastern Mediterranean. Bull. Research Council Israel, 7 (B): 1-126.

INGLE, R. W., 1980. British crabs: 1-222, figs. I-III, pls. 1-34 (British Museum (Natural History), London).

- -, 1985. Northeastern Atlantic and Mediterranean hermit crabs (Crustacea: Anomura: Paguroidea: Paguridae). I. The genus Pagurus Fabricius, 1775. Journ. nat. Hist., London, 19: 745-769.

_- 1993. Hermit crabs of the northeastern Atlantic Ocean and Mediterranean Sea. An illustrated key: i-vi, 1-495, figs. 1-147 (British Museum (Natural History), London).

Koukouras, A., 1973. Contribution to the study of the Decapod Crustacea of Greece. Hellenic Oceanol. Limnol., 11: 745-770.

Koukouras, A., K. Dounas, M. Türkay \& E. Voultsiadou-Koukouras, 1992. Decapod crustacean fauna of the Aegean Sea: New information, check list, affinities. Senckenbergiana marit., $22(3 / 6): 217-244$.

Lewinsohn, C. \& L. B. Holthuis, 1986. The Crustacea Decapoda of Cyprus. Zool. Verhand, Leiden, 230: 1-64.

LONGHURST, A. R., 1958. An ecological survey of the West African marine benthos. Colonial Office, Fishery Publications, 11: 1-102.

MANNING, R. B. \& C. Froglia, 1982. On a collection of Decapod Crustacea from southern Sardinia. Quad. Lab. Tecnol. Pesca, 3 (2-5): 319-334.

Manning, R. B. \& L. B. Holthuis, 1981. West African brachyuran crabs (Crustacea: Decapoda). Smithsonian Contrib. Zool., 306: 1-379.

MANNING, R. B. \& L. B. Holthuis, 1989. Two new genera and nine new species of Geryonid crabs (Crustacea, Decapoda, Geryonidae). Proc. Biol. Soc. Washington, 102 (1): 50-77.

Manning, R. B. \& Z. ŠTEvČIć, 1982. Decapod fauna of the Piran Gulf. Quad. Lab. Tecnol. Pesca, $3(2-5): 285-304$.

MONOD, Th., 1956. Hippidea et Brachyura ouest-africains. Mémoires de l'Institut Français d'Afrique Noire, 45: 1-674.

MurA, M. \& A. CAU, 1994. Community structure of the decapod crustaceans in the middle bathyal zone of the Sardinian Channel. Crustaceana, 67 (3): 259-266.

Nouvel, H. \& L. B. Holthuis, 1957. Les Processidae (Crustacea, Decapoda, Natantia) des eaux européennes. Zool. Verhand., Leiden, 32: 1-53.

NuÑES-Ruivo, L., 1961. Crustacea Decapoda (I - Galatheidea et Brachyura). Résultats Scientifiques de la Campagne du N.R.P. "Faial" dans les eaux côtières du Portugal (1957), 4: $1-36$.

PASTORE, M., 1976. Decapoda Crustacea in the Gulf of Catania with a discussion of a new species of Dromiidae (Decapoda: Brachyura) in the Mediterranean Sea. Thalassia Jugoslavica, 8 (1): 105-117.

- - 1984. Paguristes streaensis n. sp., della costa jonico-salentina. Thalassia Salentina, 14: 16-27.

Pastore, M. \& R. VacCarella, 1977. Crostacei decapodi del porto di Bari. Oebalia, 3: 33-63.

PÉRÈS, J. M., 1985. History of the Mediterranean biota and the colonization of the depths. In: R. MARGALEF (ed.), Key environments: Western Mediterranean: 198-244.

PÉRÈS, J. M. \& J. PICARD, 1964. Nouvel manuel de bionomie benthique de la Mer Méditerranée. Rec. Trav. Sta. mar. Endoume, 31 (47): 1-37.

Pipitone, C. \& M. L. Tumbiolo, 1993. Decapod and Stomatopod Crustaceans from the trawlable bottoms of the Sicilian Channel (Central Mediterranean Sea). Crustaceana, 65 (3): 358-364.

SAINT LAURENT, M. DE, 1971. Paguristes syrtensis, espèce nouvelle des côtes tunisiennes (Crustacea Decapoda Diogenidae). Bull. Mus. natn. Hist. nat., Paris, 42 (5): 1099-1107. 
SARÀ, R., 1969. La pesca a strascico sui fondali della scarpata continentale (settori di Levanz di Pantelleria). Mem. Min. Mar. Mer., 21.

SARDÁ, F. \& I. PALOMERA, 1981. Crustáceos Decápodos capturados durante la campaña "Medi1 raneo II" (Marzo, 1977) en el Mar Catalan. Res. Exp. Cient., 9: 143-150.

Schembri, P. J., \& E. LANFrAnco, 1984. Marine Brachyura (Crustacea: Decapoda: Brachyu from the Maltese Islands and surroundin waters (Central Mediterranean). Centro, 1 (1): 21 ŠTEVČIĆ, Z., 1979. Contribution à la connaissance des crustacés décapodes de Malta. Rapp. Com Int. Mer Mediterranée, 25/26 (4): 127-128.

- - 1990. Check-list of the Adriatic decapod Crustacea. Acta Adriatica, 31 (1-2): 183-274.

TÜRKAY, M., 1976. Die madeirensischen Brachyuren des Museu Municipal do Funchal und c Forschungs-Instituts Senckenberg, I: Familien Dromiidae, Homolidae, Calappidae, Leuco idae, Cancridae, Portunidae, Xanthidae, Geryonidae, Goneplacidae und Palicidae (Crustact Decapoda). Boletim do Museu Municipal do Funchal, 30: 57-74.

VAso, A. \& L. GJIKNURI, 1993. Decapod Crustaceans of the Albanian coast. Crustaceana, 65 ( 390-407.

ZariQuiey Alvarez, R., 1968. Crustáceos Decápodos Ibéricos. Inv. Pesq. Barcelona, 32: 1-51 